\title{
Effects of ambient ozone on lung function in children over a two- summer period
}

\author{
M.V. Kopp*, W. Bohnet*, T. Frischer", C. Ulmer*, M. Studnicka ${ }^{+}$, G. Ihorst*, C. Gardner*, \\ J. Forster*, R. Urbanek", J. Kuehr*
}

Effects of ambient ozone on lung function in children over a two-summer period. M.V. Kopp, W. Bohnet, T. Frischer, C. Ulmer, M. Studnicka, G. Ihorst, C. Gardner, J. Forster, R. Urbanek, J. Kuehr. ERS Journals Ltd 2000.

ABSTRACT: There is a general consensus that short term exposure to ozone $\left(\mathrm{O}_{3}\right)$ causes a decrease in lung function parameters such as forced vital capacity (FVC) and forced expiratory volume in one second (FEV1). The objective of this study was to assess the reproducibility of lung function decrements after ambient $\mathrm{O}_{3}$ exposure over a two-summer period.

The authors studied 797 children with a mean age of 8.2 yrs $(95 \%$ confidence interval: 6.9-9.5) from the second and third grades of ten elementary schools in Austria and southwestern Germany. At the outset the various study locations were stratified into three groups with low $(\mathrm{L})$, medium $(\mathrm{M})$ and high $(\mathrm{H}) \mathrm{O}_{3}$ exposure (range of mean $\mathrm{O}_{3}$ concentration in the locations April-October 1994: 24-30 (L); 3338 (M); 44-52 (H) parts per billion (ppb)). Four lung function tests were performed on each child between March 1994 and November 1995.

The increases in FVC and FEV1 recorded from one test period to the next were expressed as $\mathrm{mL} \cdot \mathrm{day}^{-1}$. A significantly lower FVC and FEV1 increase was observed in children exposed to high ambient $\mathrm{O}_{3}$ concentration during the summer season. (FVC in summer 1994: $0.83(\mathrm{~L}) ; 0.56(\mathrm{M}) ; 0.55(\mathrm{H}) \mathrm{mL}^{-\mathrm{day}^{-1}} ; \mathrm{p}=0.004$; and summer 1995: $0.80(\mathrm{~L}) ; 0.63(\mathrm{M}) ; 0.56(\mathrm{H}) \mathrm{mL} \cdot \mathrm{day}^{-1} ; \mathrm{p}=0.011 ; \mathrm{FEV} 1$ in summer 1994: $0.48(\mathrm{~L}) ; 0.34$ (M); 0.18 (H) $\mathrm{mL}^{\cdot \mathrm{day}^{-1}} ; \mathrm{p}=0.004$ and summer 1995: 0.68 (L); $0.45(\mathrm{M}) ; 0.41$ (H) $\left.\mathrm{mL}^{-d_{a y}}{ }^{-1}, \mathrm{p}=0.006\right)$. There was no significant difference in FVC or FEV1 increase between the groups during the winter period. Adjusting for sex, age, height and passive smoke exposure, linear regression revealed a statistically significant negative association of average ambient $\mathrm{O}_{3}$ concentration with the FVC and FEV1 increase in both summers. During the winter period no association of $\mathrm{O}_{3}$ with $\mathrm{FVC}$ or FEV1 was observed.

In conclusion, in two consecutive summer periods the authors found reproducible lung function decrements in children exposed to high levels of ambient ozone. Reoccurrence of ozone associated lung function deficits might increase the likelihood of persisting effects on the childrens' airways.

Eur Respir J 2000; 16: 893-900.

Laboratory studies of volunteers exposed to high ozone $\left(\mathrm{O}_{3}\right)$ concentrations in chambers and in epidemiological field studies both have revealed an $\mathrm{O}_{3}$ related decline in lung function parameters such as forced vital capacity (FVC), forced expiratory volume in one second (FEV1) and peak expiratory flow (PEF) [1-4]. Since children spend more time outdoors and are physically more active than adults and as the growing lung might be more susceptible, they are regarded as a potential risk population for $\mathrm{O}_{3}$ induced health effects.

The authors recently published data from a follow-up study with school-aged children living in two small cities in southwestern Germany [5]. A negative association between $\mathrm{O}_{3}$ exposure under natural living conditions and lung function (FVC, FEV1) for the subpopulation living in the city with higher $\mathrm{O}_{3}$ levels during the summer season 1994 was demonstrated. A decrease in the FVC of approximatley $12.31 \mathrm{~mL} \cdot 10 \mu \mathrm{g} \cdot \mathrm{m}^{3} \mathrm{O}_{3}$ and in the $\mathrm{FEV} 1$ of
*University Childrens Hospital, Freiburg, Germany. "University Childrens Hospital, and ${ }^{+}$Pulmologic Centre, First Internal Dept, Vienna, Austria.

Correspondence: T. Frischer

Allgemeines Krankenhaus Wien

Währinger Gürtel 18-20

A-1090 Wien

Fax: 431404003189

\section{Keywords: Children}

chronic exposure

forced expiratory volume in one second

forced vital capacity

ozone

Received: April 191999

Accepted after revision July 32000

The study was supported by a grant from the Federal State of Baden-Württemberg ("Projekt Umwelt und Gesundheit"; PUG 94 001) and a grant from the Fonds zur Foerderung der wissenschaftlichen Forschung, Austria ("09507 MED")
$11.29 \mu \mathrm{mL} \cdot 10 \mu \mathrm{g} \cdot \mathrm{m}^{3} \mathrm{O}_{3}$ was calculated for the study population living in this city. Earlier studies had reported a decrease in FVC of $0.0275-0.5 \mathrm{~mL} \cdot \mu \mathrm{g} \cdot \mathrm{m}^{3} \mathrm{O}_{3}$ and for FEV1 of $0.15-0.7 \mathrm{~mL} \cdot \mu \mathrm{g} \cdot \mathrm{m}^{3} \mathrm{O}_{3}$ under natural conditions [6-8], or during physical exercise or in summer camps [9-14].

In contrast to the short-term health effects of ozone, there are few studies that have investigated the possible long term health effects of ozone in humans due to problems with exposure assessment and the coincident effects of other pollutants. Reduced levels of FVC and FEV1 after prolonged ozone exposure were reported in both children and adults $[15,16]$. However, the crosssectional design of these studies does not allow for an investigation into the cause-effect relationship, because outcome as well as exposure is assessed at the same time.

Repeated lung-function testing was therefore performed over two years in ten communities with differing levels of 
ambient ozone exposure. The purpose of the present study was to assess the reproducibility of lung function decreases and to investigate the possible long lasting effects of ambient ozone and changes in forced vital capacity or forced expiratory volume in one second, in children, under normal living conditions, over a 20 -month period. The children had been analysed in a previous study and were included in part of the present data [17].

\section{Materials and methods}

\section{Study design}

This longitudinal field study on $\mathrm{O}_{3}$ induced changes in the lung function of schoolchildren, included subjects from the second and third grade of eight elementary schools in Austria (Amstetten: altitude $270 \mathrm{~m}$; St Valentin: $242 \mathrm{~m}$; Krems: 190 m; Heidenreichstein: 560 m; Gänserndorf: 161 m; Mistelbach: $250 \mathrm{~m}$; Wiesmath: $738 \mathrm{~m}$; Bruck: $210 \mathrm{~m}$ ) and two elementary schools situated in the Black Forest in southwestern Germany (Villingen: $270 \mathrm{~m}$; Freudenstadt: $730 \mathrm{~m}$ ). From the ten sites selected, six were rural communities with a population size of $<10,000$ and four were towns with a population size of 20,000-30,000. The study sites were selected on the basis of the 1991-1993 annual average ozone concentration to represent a broad range of average long-term $\mathrm{O}_{3}$ exposure.

Sites with major industries in the vicinity were excluded to reduce confounding by other pollutants. Where there was more than one school in a community, school authorities suggested a specific school that was then invited to participate.

The field study was carried out March 1994-November 1995. All technical details (questionnaire, exposure assessment, lung function protocol, statistical analysis) were standardized before the beginning of the study. The study protocol was approved by the local ethics committee and written consent was obtained from the parents.

\section{Population}

A total of 797 pupils with a mean age of 8.2 yrs $(95 \%$ confidence interval (CI): 6.9-9.5) performed four lung function tests during spring 1994 and autumn 1995. Parents of children enrolled in grade two and three of ten elementary schools were asked to participate. After informed consent for the study had been obtained, a questionnaire was distributed in the schools to be filled out by the parents at home. The participation at the start of the study ranged $90.2-96.3 \%$ for the ten sites.

\section{Questionnaire}

The standardized questionnaire was filled out prior to the first examination. For assessment of respiratory history the International Study of Asthma and Allergies in Childhood (ISAAC) questionnaire was used. A diagnosis of asthma or recurrent diagnoses of wheezy bronchitis by the doctor were considered as being asthma. A child's past 12month history of respiratory symptoms (shortness of breath, wheeze, cough at night, cough following exercise) was ascertained as well as current passive smoke exposure at home. Passive smoke exposure was defined to be present if smoking of at least one cigarette day $^{-1}$ was reported.

\section{Skin prick test}

The skin prick test was performed on the volar surface of the forearm using extracts from hazel, birch and grass pollens, dog and cat dander and dust mites (Dermatophagoides farinae, Dermatophagoides pteronyssinus) with histamine hydrochloride $\left(10 \mathrm{mg} \cdot \mathrm{mL}^{-1}\right)$ and sodium chloride $\left(9 \mathrm{~g} \cdot \mathrm{L}^{-1}\right)$ as control solutions. The allergens (ALKScherax, Hamburg, Germany) corresponded to a concentration of 10 histamine equivalent potency (HEP). All skin reactions were evaluated after $15 \mathrm{~min}$. A mean diameter $\geq 2 \mathrm{~mm}$ together with a ratio of allergen wheal: histamine wheal $>0.5$ was considered to be a positive reaction [18].

\section{Pulmonary function testing}

Four pulmonary function tests (flow/volume curves) were performed at school during or after regular teaching hours by two teams using a Masterscope (Software Release 4.0; Erich Jaeger, Wuerzburg, Germany). Because the authors were interested in the average effects of ozone exposure, they minimized confounding by short-term high ozone exposure during summer, by analysing tests from March-May and September-November. The instruments were calibrated daily. In each test every child performed two forced expiratory manoeuvres, according to the American Thoracic Society (ATS) guidelines, in a standing position wearing a noseclip. On each occasion at least two reproducible flow/volume curves requiring a difference in FVC $\leq 5 \%$ were achieved. The highest FVC and FEV1 values were statistically analysed, but only children who had participated in all four tests were included. Height was measured before each of the four tests. For descriptive purposes the observed FVC and FEV1 values were related to reference values based on height and gender [19] and were expressed as a percentage of the predicted mean. The same protocol and equipment was employed in Austria and Germany and the field workers of both countries were trained at central location prior to the beginning of the study.

\section{Exposure data}

The concentrations of $\mathrm{O}_{3}$, nitrogen dioxide $\left(\mathrm{NO}_{2}\right)$, sulphur dioxide $\left(\mathrm{SO}_{2}\right)$ and particles with a $50 \%$ cut-off aerodynamic diameter of $10 \mu \mathrm{m}$ (PM10) were measured at each of the listed locations in the vicinity of the schools. The monitor stations were run by local authorities and provided 30-min means of $\mathrm{O}_{3}, \mathrm{NO}_{2}, \mathrm{SO}_{2}$.

For $\mathrm{O}_{3}$, the ultraviolet (UV) absorption method (Germany: KS-212-1012.10, Vorabscheider, Kalman System, Hungary; Austria: ML 8810 Monitor Labs, San Diego, CA, USA) was used. $\mathrm{SO}_{2}$ and $\mathrm{NO}_{2}$ were also measured with fixed monitors based on fluorescence (ML 8841 Monitor Labs) and chemiluminescence (ML 8840 Monitor Labs) methods, respectively. The measurements were taken by the regional environmental protection agency and were reviewed by the study team for consistency and completeness.

PM10 was measured in Austria gravimetrically on filters by using samplers equipped with $10 \mu \mathrm{m}$-inlets $(37 \mathrm{~mm}$ teflon filters with a polyolefin ring, 2.0 micron pore size). 
Fourteen-day average levels were used for analysis since monitor stations were visited regularly by technicians within this time interval. Filters were provided by the Harvard School for Public Health (Boston, MA, USA) for exposure assessment and all filters were also weighed there. In Germany, PM10 was continuously measured with the beta-absorption-method (FAG, FH 62 IN, Eberlin, Germany).

\section{Statistical analysis}

The differences between the consecutive tests 1 and 2, 2 and 3 and 3 and 4 were calculated for FVC and FEV1 and were divided by the number of days between the tests. These average daily growth-related increases were expressed as $\mathrm{mL} \cdot \mathrm{day}^{-1}$.

Two different linear regression models were chosen to describe a possible effect of $\mathrm{O}_{3}$ on average daily increases in FVC and FEV1 (surrogate of lung growth). Firstly, the population was divided into three groups according to the $\mathrm{O}_{3}$ exposure observed in the region. These groups represented regions with low $\mathrm{O}_{3}$ exposure (L), medium $\mathrm{O}_{3}$ exposure $(\mathrm{M})$ and high $\mathrm{O}_{3}$ exposure $(\mathrm{H})$. Besides the $\mathrm{O}_{3}$ exposure, the models include sex, age, height, passive smoke exposure and study country as independent variables. The regression model gives parameter estimates for the differences between these three groups as a description of possible $\mathrm{O}_{3}$ effects.

An exposure-response-relationship between $\mathrm{O}_{3}$ exposure and lung growth was then established by calculating the mean $\mathrm{O}_{3}$ concentration for each test period. A negative parameter estimate could then be interpreted as the degree of lung function decrease when mean $\mathrm{O}_{3}$ exposure was on the increase. All analyses were performed using the Statistical Analysis System (SAS, Heidelberg, Germany).

\section{Results}

A total of 797 children participated in all four lung function tests between spring 1994 and autumn 1995. The distribution of the main characteristics of the analysed population is presented in table 1. Mean age was higher in the Freudenstadt and Villingen population. The sensitization to pollen ranged between $21.2 \%$ (St. Valentin) and $6.2 \%$ (Wismath). On average, the doctor diagnosed lifetime prevalence of bronchial asthma was $3.7 \%$. The asthma prevalence was low in Heidenreichstein and Wismath $(0 \%$ and $1 \%)$ compared to Freudenstadt and Amstetten (7.3 and 6.9\%). One possible explanation for this finding may be attributed to the different habits of the local paediatricians either in using the diagnosis "asthma" and "wheezing bronchitis" in children or informing the parents about the diagnosis.

On average, $35 \%$ of the children were exposed to passive smoking. The passive smoke exposure in the high ozone exposed study sites ranged $21.2-34.6 \%$, whereas in group $\mathrm{M}$ and $\mathrm{L}$ the passive smoke exposure was higher and ranged $26.9-61.6 \%$.

The $\mathrm{O}_{3}, \mathrm{NO}_{2}, \mathrm{SO}_{2}$ and PM10 concentrations at the different locations during the winter and summer period are given in table $2 . \mathrm{O}_{3}, \mathrm{NO}_{2}$ and $\mathrm{SO}_{2}$ exposure were calculated by taking the mean of all 30-min means collected April-September and October-March in both 1994 and 1995.

Based on the mean $\mathrm{O}_{3}$ exposure April-October 1994, Amstetten, St. Valentin, Krems and Villingen were allocated to the low group (L) with mean $\mathrm{O}_{3}$ exposure 24-33 ppb; Heidenreichstein, Gänserndorf and Mistelbach were defined as medium $\mathrm{O}_{3}$ exposed group (M) with mean $\mathrm{O}_{3}$ exposure of 35-38 ppb; and Wiesmath, Bruck and Freudenstadt were allocated to the highly exposed group $(\mathrm{H})$ with ambient $\mathrm{O}_{3}$ exposure 44-52 ppb. The Spearman correlation coefficients between $\mathrm{O}_{3}$ and the other pollutants

Table 1. - Main characteristics of the study population

\begin{tabular}{|c|c|c|c|c|c|c|c|c|c|c|c|}
\hline Variable & $\begin{array}{l}\text { Total } \\
\text { popu- } \\
\text { lation }\end{array}$ & Amstetten & $\begin{array}{c}\text { St. } \\
\text { Valentin }\end{array}$ & Krems & Villingen & $\begin{array}{l}\text { Heiden- } \\
\text { reichstein }\end{array}$ & $\begin{array}{l}\text { Gänsern- } \\
\text { dorf }\end{array}$ & $\begin{array}{l}\text { Mistel- } \\
\text { bach }\end{array}$ & Wiesmath & Bruck & $\begin{array}{l}\text { Freuden- } \\
\text { stadt }\end{array}$ \\
\hline Subjects $n$ & 751 & 57 & 57 & 106 & 75 & 67 & 66 & 119 & 104 & 45 & 55 \\
\hline Sex female $\%$ & 58.2 & 44.7 & 50.9 & 51.9 & 37.3 & 49.3 & 45.6 & 45.4 & 48.1 & 51.1 & 65.5 \\
\hline Age $\%$ & $\begin{array}{c}8.2 \\
(69-95)\end{array}$ & $\begin{array}{c}7.8 \\
(69-8.8)\end{array}$ & $\begin{array}{c}8.2 \\
(70-93)\end{array}$ & $\begin{array}{c}8.0 \\
(68-87)\end{array}$ & $\begin{array}{c}9.1 \\
(8.1-112)\end{array}$ & $\begin{array}{c}7.9 \\
(69-90)\end{array}$ & $\begin{array}{c}7.7 \\
(70-8.8)\end{array}$ & $\begin{array}{c}7.8 \\
(6.8-8.8)\end{array}$ & $\begin{array}{c}7.8 \\
(68-86)\end{array}$ & $\begin{array}{c}7.8 \\
(70-89)\end{array}$ & $\begin{array}{c}8.9 \\
(80-104)\end{array}$ \\
\hline $\begin{array}{l}\text { Doctor diag- } \\
\text { nosed asthma \% }\end{array}$ & 3.7 & 6.9 & 3.7 & 4.8 & 4.0 & 0 & 4.5 & $\begin{array}{l}2.5 \\
2.0\end{array}$ & $\begin{array}{l}(0.0) \\
1.0\end{array}$ & 2.2 & 7.3 \\
\hline $\begin{array}{l}\text { Symptoms of } \\
\text { wheezing in the } \\
\text { last } 12 \text { months \% }\end{array}$ & 9.0 & 11.7 & 8.9 & 10.5 & 8.1 & 12.3 & 6.1 & 6.7 & 3.9 & 13.3 & 12.7 \\
\hline $\begin{array}{l}\text { Exposure to } \\
\text { passive smok- } \\
\text { ing } \%\end{array}$ & 35.3 & 36.3 & 33.9 & 47.1 & 61.6 & 29.7 & 34.4 & 26.9 & 21.2 & 29.6 & 34.6 \\
\hline $\begin{array}{l}\text { Sensitization to } \\
\text { pollen allergens } \\
\%\end{array}$ & 12.2 & 13.9 & 21.2 & 10.8 & 15.5 & 12.3 & 9.8 & 8.0 & 6.2 & 16.2 & 16.4 \\
\hline $\begin{array}{l}\text { FVC \% pred in } \\
\text { test } 1\end{array}$ & 103.7 & 104.2 & 99. & 105.2 & 107.7 & 103.8 & 102.3 & 101.0 & 101.6 & 103.8 & 103.4 \\
\hline $\begin{array}{l}\text { FEV1 \% pred in } \\
\text { test } 1\end{array}$ & 107.9 & 108.6 & 104.7 & 109.0 & 109.2 & 110.3 & 109.0 & 106.7 & 109.1 & 105.0 & 102.3 \\
\hline
\end{tabular}

*: data are presented as mean $\left(95 \%\right.$ confidence interval) or $^{+}$: mean. FVC: forced vital capacity; FEV1: forced expiratory volume in one second. 


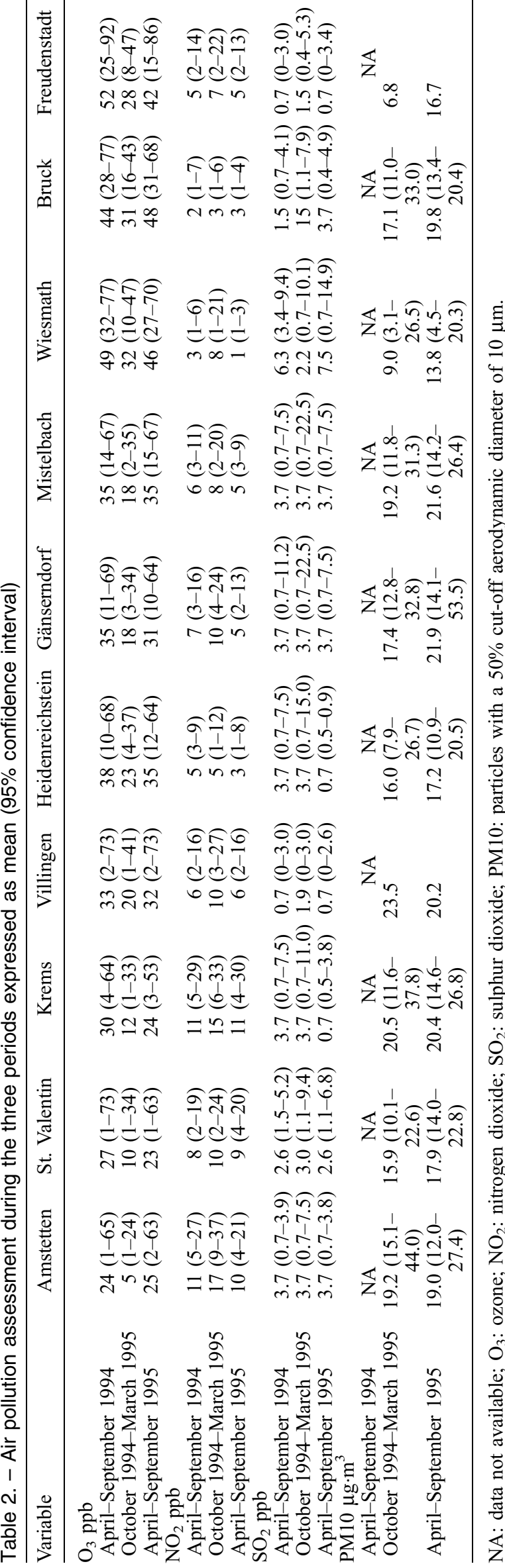

(mean of all 1/2h-means of $\mathrm{NO}_{2}, \mathrm{SO}_{2}$ and PM10 between summer 1994: April-September; winter 1994/95: October-March; summer 1995: April-September) are presented in table 3. There was no strong positive correlation between $\mathrm{O}_{3}$ and the other pollutants, especially for $\mathrm{NO}_{2}$ and PM10 where the effect was opposite to that of $\mathrm{O}_{3}$. During both summer seasons a positive correlation was calculated between $\mathrm{O}_{3}$ and $\mathrm{SO}_{2}$, however, the correlation coefficient was not significant. These findings suggest an $\mathrm{O}_{3}$ effect and the confounding effects of other air pollutants seem to be negligible.

Figures 1 and 2 show FVC and FEV1 for the four lung function tests in the three groups. As expected, FVC and FEV1 increased over the study period. FVC and FEV1 were higher than the predicted values in all study locations with the exception of FVC in St. Valentin (table 1). Changes in FVC and FEV1 during the different intervals from consecutive tests 1 to 2,2 to 3 , and 3 to 4 were calculated in $\mathrm{mL} \cdot \mathrm{day}^{-1}$ (figs. 3 and 4). There was a tendency for a lower FVC and FEV1 increase in group $\mathrm{H}$ with high ambient $\mathrm{O}_{3}$ concentration during summer seasons 1994 and 1995 (tests 1 to 2 and 3 to 4). During Winter children in group $\mathrm{M}$ and $\mathrm{H}$ showed a slightly higher increase in FEV1 and FVC compared to children of group L.

The linear regression model shows that during summer 1994 and 1995 the FVC increase was significantly lower in group $\mathrm{M}$ and $\mathrm{H}$ (table 4). This is also the case for FEV1 with the exception of group M in 1994. Regarding FVC, a negative parameter estimate of -0.278 $\mathrm{mL}$.day.ppb $\mathrm{O}_{3}{ }^{-1}$ was calculated during summer 1994 and $-0.266 \mathrm{~mL} \cdot$ day.ppb $\mathrm{O}_{3}^{-1}$ during summer 1995 when comparing the low exposure group with the high exposure group. For FEV1 a negative parameter estimate of $-0.303 \mathrm{~mL} \cdot$ day.ppb ${ }_{3}{ }^{-1}$ during summer 1994 and -0.322 $\mathrm{mL} \cdot$ day.ppb $\mathrm{O}_{3}^{-1}$ during summer 1995 was calculated when comparing the low with the high exposure group. During the winter period a positive parameter estimate for $\mathrm{FVC}$ and FEV1 increase was calculated in the group $\mathrm{M}$ and $\mathrm{H}$ (table 4).

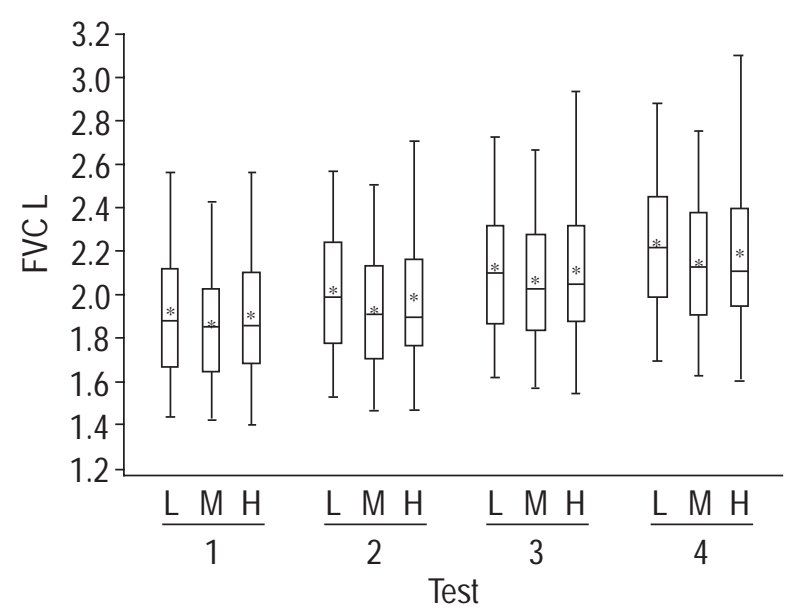

Fig. 1. - Forced vital capacity values over the four lung function tests in the three groups above the four test points. The boxes include the interval between the 25th and 75th percentile. The extremes represent the 5th and 95th percentile, the median is shown as a horizontal line in the box and the mean as a star. Adjusted for height and gender. 
Table 3. - Spearman Correlation Coefficients of the local seasonal mean concentration

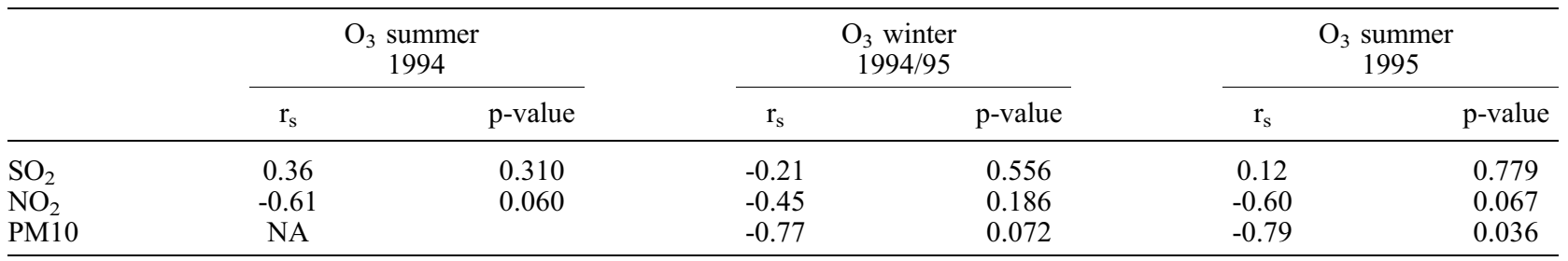

Data are presented as mean of 0.5-means between summer 1994: April-September; winter 1994/95: October-March; summer 1995: April-September of the air pollutants over the three test periods. $\mathrm{O}_{3}$ : ozone; $\mathrm{SO}_{2}$ : sulphur dioxide; $\mathrm{NO}_{2}$ : nitrogen dioxide; PM10: particles with a $50 \%$ cut-off aerodynamic diameter of $10 \mu \mathrm{m}$; NA: data not available.

In a second model the $\mathrm{O}_{3}$ effect on FVC and FEV1 increase in the total population is described (table 5). $\mathrm{O}_{3}$ exposure is assessed by the mean concentration of $\mathrm{O}_{3}$ during the test periods for each child in each location. Again a statistically significant parameter estimate of ambient $\mathrm{O}_{3}$ concentration on FVC and FEV1 increase in both summer periods was calculated, and a positive parameter estimate for FVC and FEV1 increase was calculated in the group $\mathrm{M}$ and $\mathrm{H}$ during the winter period. No effect of $\mathrm{SO}_{2}$ and $\mathrm{PM} 10$ on FVC increase was observed during summer 1995 and winter 1994/5, whereas $\mathrm{SO}_{2}$ was negatively associated with $\mathrm{FVC}$ increase during summer 1994. $\mathrm{NO}_{2}$ was negatively associated with FVC increase during winter but had a positive effect on FVC increase during both summer seasons.

\section{Discussion}

In a population based sample of 797 children, a reproducible effect of a lower FVC and an increased FEV1 in children exposed to high ambient $\mathrm{O}_{3}$ concentrations, during the summer season, compared to children exposed to lower ambient $\mathrm{O}_{3}$ concentrations, was observed in two consecutive years. The observations in this study points towards longer lasting $\mathrm{O}_{3}$ effects on children exposed to ambient $\mathrm{O}_{3}$ levels.

In this analysis, data sets of two study sites in Germany and eight sites in Austria were analysed. The German

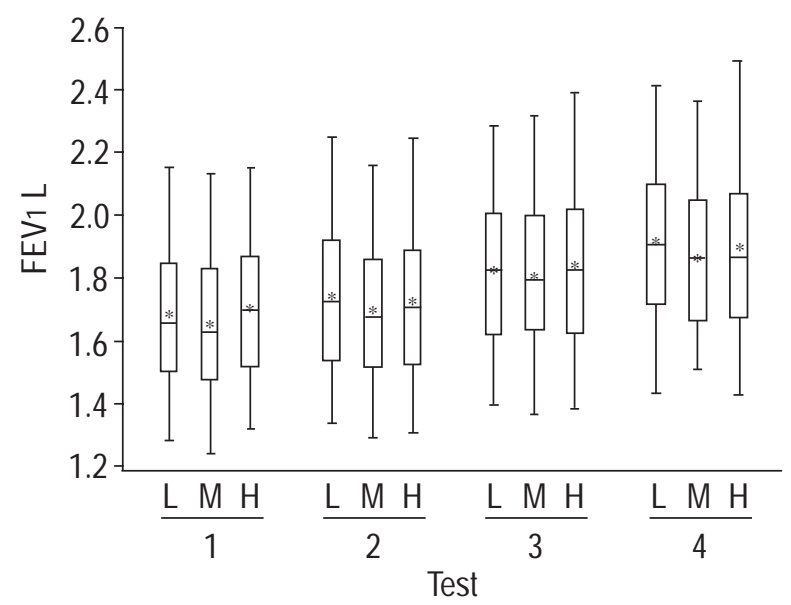

Fig. 2. - Forced expiratory volume in one second values over the four lung function tests in the three groups above the four test points. The boxes include the interval between the 25 th and 75 th percentile. The extremes represent the 5 th and 95 th percentile, the median is shown as a horizontal line in the box and the mean as a star. population was approximately one year older. All technical details were standardized before the beginning of the study and the teams were trained centrally. These data sets were used to increase the statistical power and to analyse a wider range of exposure than in a previous analysis carried out by the authors [17]. The children living in Freudenstadt were highly exposed to $\mathrm{O}_{3}$ compared to the majority living in Austria. The aim of the analysis was to study the reproducibility of $\mathrm{O}_{3}$ effects in a two-year period and the possibility of a longer lasting health effect. Because a follow-up study was not performed in the children from Germany, only the Austrian part of the study will address the question of chronic effects on lung growth.

The importance of taking a broad range of $\mathrm{O}_{3}$ exposed study sites into account is highlighted by the fact that FVC and FEV1 increase differed not only between the $\mathrm{H}$ and the $M$ exposed group but even between the $L$ and the $M$ exposed group. This finding is in accordance with the existence of a linear dose-response relationship.

Even if epidemiological studies are the appropriate approach to investigate possible adverse health effect of air pollutants, there are a few intrinsic difficulties, and several potential biases. One major problem is an adequate exposure assessment. The ozone exposure of each child was calculated by taking the mean of all 2-h means collected between the summer season (April-September) and the winter time interval (October-March), respectively. However, these means might differ from individual

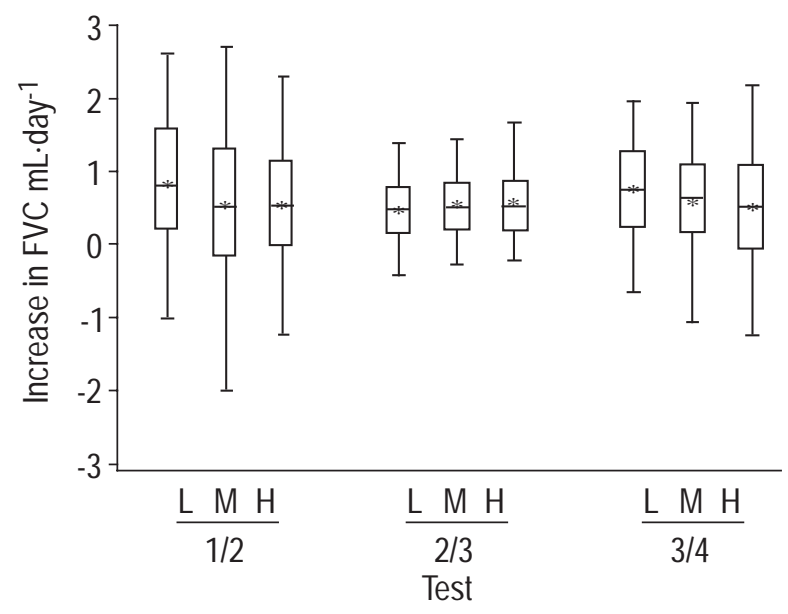

Fig. 3. - Forced vital capacity increase from test 1 to test 2 , from test 2 to test 3 and from test 3 to test 4 expressed as change from the proceeding test. The boxes include the interval between the 25 th and 75 th percentile. The extremes represent the 5 th and 95 th percentile, the median is shown as a horizontal line in the box and the mean as a star. 


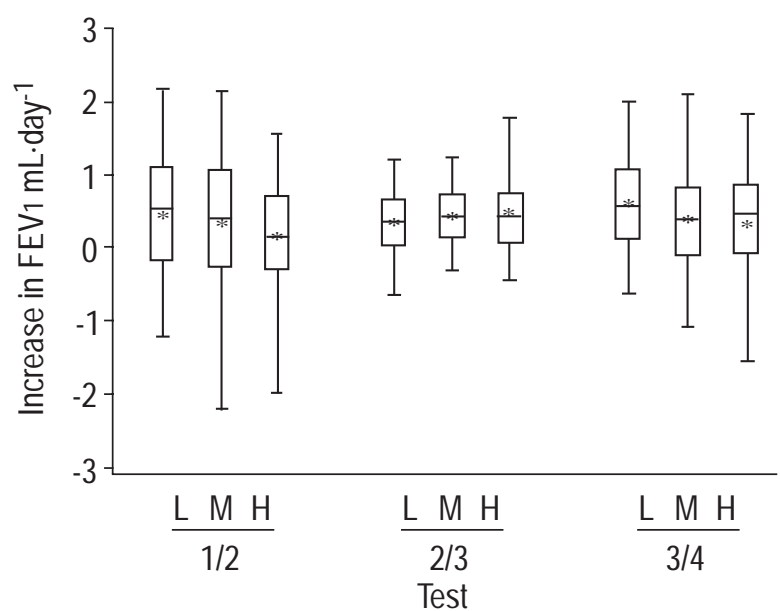

Fig. 4. - Forced expiratory volume in one second increase from test 1 to test 2 , from test 2 to test 3 and from test 3 to test 4 expressed as change from the proceeding test. The boxes include the interval between the 25 th and 75 th percentile. The extremes represent the 5th and 95th percentile, the median is shown as a horizontal line in the box and the mean as a star.

exposure, as children have different time intervals spent outdoors. It must be emphasized that the chosen method of calculating $\mathrm{O}_{3}$ exposure is an "estimate" and in this sense only a surrogate parameter for the real exposure. Personal $\mathrm{O}_{3}$ samplers would have mirrored the individual exposure more precisely, although physical activities and therefore, the biologically inhaled dose were difficult to measure accurately. Furthermore, it was not possible to provide all 797 children with personal ozone samplers. However, recently published longitudinal studies calculated air pollutant exposure in a very similar way [19]. Therefore, the described approach of exposure assessment was selected.

Moreover, exposure to air pollutants is multidimensional, generally consisting of a mixture of different gases. Similar to $\mathrm{O}_{3}$, exposure to other environmental air pollutants $\left(\mathrm{NO}_{2}, \mathrm{SO}_{2}\right.$ or total suspended particulates (TSP)/ PM10) was calculated. Coincident effects of other air pollutants is a major source of potential bias. To address this issue, study locations free of industry in the vicinity were selected and characterized by low concentrations of $\mathrm{NO}_{2}$ and $\mathrm{SO}_{2}$. The mean concentrations of $\mathrm{NO}_{2}$ and $\mathrm{SO}_{2}$ are relatively low compared to the National Ambient Air Quality Standards (NAQS) of the US Environmental Protection Agency Office $\left(\mathrm{NO}_{2}\right.$ : NAAQS $<53 \mathrm{ppb}$ annual arithmetic mean; $\mathrm{SO}_{2}$ : NAAQS $<140 \mathrm{ppb}$ annual arithmetic mean) [17].
The relatively low concentrations of $\mathrm{NO}_{2}$ and $\mathrm{SO}_{2}$ make a causative relationship with lung function changes unlikely and confounding effects of other air pollutants seem to be negligible. The PM10 data for winter 1994/95 and summer 1995 only, is presented. As demonstrated by SPENGLER et al. [21], fine particle concentrations are highly correlated with $\mathrm{O}_{3}$ exposure in the US. No significant correlation between $\mathrm{O}_{3}$ and $\mathrm{PM} 10$ was found in this study.

The influence of pollutants other than $\mathrm{O}_{3}$ on lung function parameters was investigated and the linear regression model to assess the possible effects of $\mathrm{NO}_{2}, \mathrm{SO}_{2}$ and PM10 on FVC and FEV1 increase calculated (data not shown). For all these pollutants no confounding with $\mathrm{O}_{3}$ and no consistent associations with lung function parameters were observed.

Generally, the data in this study is in favour of a biological $\mathrm{O}_{3}$ effect. Nevertheless, this may in part be the effect of a complex pollutant mixture rather than an independent $\mathrm{O}_{3}$ effect. In general, expected health effects of air pollutants at concentrations found in developed countries are weak and respiratory health indicators have multiple aetiologies.

Recently JÖRRES et al. [19] reported a controlled exposure study and showed that atopic subjects might be more susceptible to $\mathrm{O}_{3}$ effects than nonatopic subjects. Based on the population sample in this study, only $3.7 \%$ suffered from bronchial asthma. Therefore, it is unlikely that the observed effect was caused by this small subgroup. In addition, the regression analysis showed no interaction between sensitization to aeroallergens and $\mathrm{O}_{3}$.

Kollipara and ConNors [23] reported that prolonged exposure to sunlight might increase the velocity of growth. As high $\mathrm{O}_{3}$ exposure is highly correlated with temperature and sun radiation, it might be speculated that the physiological somatic growth velocity in children is greater in summer and physiological lung growth follows a slight delay during autumn and winter. To test this hypothesis the growth velocity in the three exposure groups was calculated. In the regions with $\mathrm{L}, \mathrm{M}$ and $\mathrm{H} \mathrm{O}_{3}$ exposure parallel lung and somatic growth during summer 1994 and winter 1994/95 was observed. In summer 1995 group M showed a slightly higher rate of somatic growth compared to group L or H. No tendency could be seen for increased growth velocity in the group with high ambient $\mathrm{O}_{3}$ exposure.

To date, most epidemiological studies have investigated the effects of short-term exposure to $\mathrm{O}_{3}$ on symptoms, lung function, methacholine responsiveness as well as inflammatory changes and cell damage to upper and lower

Table 4. - Linear regression model calculating a potential ozone effect on increases in forced vital capacity and forced expiratory volume in one second in the three groups with low, medium and high ozone exposure adjusting for sex, age, height and passive smoke exposure

\begin{tabular}{lcccrc}
\hline Period & Group & ${\text { PE for } \mathrm{O}_{3} \text { on FVC ppb }}$ & p-value & PE for O $_{3}$ on FEV1 ppb & p-value \\
\hline Summer 1994 test 1 and 2 & $\mathrm{M}$ & -0.242 & 0.018 & -0.117 & 0.210 \\
& $\mathrm{H}$ & -0.278 & 0.022 & -0.303 & 0.007 \\
Winter 1994/95 test 2 and 3 & $\mathrm{M}$ & 0.129 & 0.005 & 0.105 & 0.030 \\
& $\mathrm{H}$ & 0.0954 & 0.078 & 0.158 & 0.006 \\
Summer 1995 test 3 and 4 & $\mathrm{M}$ & -0.168 & 0.036 & -0.218 & 0.005 \\
& $\mathrm{H}$ & -0.266 & 0.005 & -0.322 & 0.001 \\
\hline
\end{tabular}

M: medium ozone exposure; H: high ozone exposure; PE: parameter estimate $\mathrm{mL} \cdot \mathrm{day}^{-1}$; FVC: forced vital capacity; FEV1: forced expiratory volume in one second. 
Table 5. - Linear regression models calculating the potential effects of ozone and other pollutants on increases in forced vital capacity and forced expiratory volume in one second

\begin{tabular}{|c|c|c|c|c|c|c|c|c|c|c|}
\hline Period & $\begin{array}{c}\mathrm{PE} \text { for } \mathrm{O}_{3} \\
\text { on } \mathrm{FVC} \\
\mathrm{ppb}\end{array}$ & p-value & $\begin{array}{c}\mathrm{PE} \text { for } \mathrm{O}_{3} \\
\text { on } \mathrm{FEV} 1 \\
\mathrm{ppb}\end{array}$ & $\mathrm{p}$-value & $\begin{array}{c}\mathrm{PE} \text { for } \mathrm{SO}_{2} \\
\text { on } \mathrm{FVC} \\
\mathrm{ppb}\end{array}$ & $\mathrm{p}$-value & $\begin{array}{c}\mathrm{PE} \text { for } \mathrm{NO}_{2} \\
\text { on } \mathrm{FVC} \\
\mathrm{ppb}\end{array}$ & p-value & $\begin{array}{l}\text { PE for } \\
\text { PM10 on } \\
\text { FVC } \mu \mathrm{g} \cdot \mathrm{m}^{3}\end{array}$ & p-value \\
\hline $\begin{array}{l}\text { Summer } 1994 \\
\text { test } 1 \text { and } 2\end{array}$ & -0.0066 & 0.012 & -0.0060 & 0.013 & -0.044 & 0.006 & 0.031 & 0.018 & NA & NA \\
\hline $\begin{array}{c}\text { Winter } 1994 / 95 \\
\text { test } 2 \text { and } 3\end{array}$ & 0.0021 & 0.156 & 0.0023 & 0.142 & 0.007 & 0.243 & -0.009 & 0.074 & 0.003 & 0.734 \\
\hline $\begin{array}{c}\text { Summer } 1995 \\
\text { test } 3 \text { and } 4\end{array}$ & -0.0064 & 0.010 & -0.0077 & 0.001 & 0.045 & 0.028 & 0.024 & 0.010 & -0.012 & 0.154 \\
\hline
\end{tabular}

$\mathrm{O}_{3}$ : ozone; $\mathrm{FEV} 1$ : forced expiratory volume in one second; $\mathrm{PE}$ : parameter estimate $\mathrm{mL} \cdot$ day $^{-1} ; \mathrm{FVC}$ : forced vital capacity; $\mathrm{SO}_{2}$ : sodium dioxide; $\mathrm{NO}_{2}$ : nitrogen dioxide; PM10: particles with a 50\% cut-off aerodynamic diameter of $10 \mu \mathrm{m}$. The data was adjusted for sex, age, height and passive smoke exposure.

airways [24-26]. Over the last decade, human exposure and epidemiological studies have clearly demonstrated decreases in FVC and FEV1 as acute health effects of $\mathrm{O}_{3}$, due to decreased inspiratory capacity rather than airway obstruction. The reported short-term $\mathrm{O}_{3}$ effect on FVC ranges $-0.0275-0.5 \mathrm{~mL} \cdot \mu \mathrm{g} \cdot \mathrm{m}^{3} \mathrm{O}_{3}$ and on FEV $1-0.15-0.7$ $\mathrm{mL} \cdot \mu \mathrm{g} \cdot \mathrm{m}^{3} \mathrm{O}_{3}$ under natural conditions [6-8], or during forced physical exercise or in Summer camp studies [9$14]$.

Long-term effects on the growing lung were primarily assessed in animal studies. Alterations in the morphology of the nasal epithelium with chronic loss of ciliated cells [27] have been described. In the lower airways of monkeys and rats, bronchiolitis with replacement of proximal alveolar Type I and Type II cells by airway cells has been observed [28-30]. TYLER et al. [28] studied the effects of $\mathrm{O}_{3}$ on lung growth in rats exposed to filtered air or to 0.64 or $0.96 \mathrm{ppm} \mathrm{O}_{3}$ for $8 \mathrm{~h} \cdot$ night $^{-1}$ for 42 nights. Rats examined at the end of the exposure period had larger saline and fixed lung volumes with greater volumes of parenchyma, alveoli and respiratory bronchioles. TYLER et al. [28] concluded that $\mathrm{O}_{3}$ inhalation by young rats alters lung growth and development in ways likely to be detrimental, and that those changes persisted after $\mathrm{O}_{3}$ exposure had been terminated [29].

CHANG et al. [30] exposed six-week-old rats to $\mathrm{O}_{3}$ in different subchronic low-level exposure patterns. After a 12 -h.day ${ }^{-1}$ exposure for 6 weeks with 0.12 and 0.25 parts per million (ppm) $\mathrm{O}_{3}$ it was found that the relative volume of the Type I epithelium, which was regarded to be a consistent and reproducible marker for cell injury and response, increased significantly by 13 and $23 \%$ over the control value following exposures for 6 weeks to 0.12 and $0.25 \mathrm{ppm}$, respectively. According to CHANG et al. the data in the present study suggests that epithelial cell reactions to low-level subchronic exposure of $\mathrm{O}_{3}$ were directly related to the cumulative oxidant concentration and that the pattern of exposure did not appear to affect the resulting degree of injury. This data implies that even under moderate $\mathrm{O}_{3}$ exposure chronic effects emerge.

However, it still remains to be demonstrated how far chronic health effects in animal studies will hold for humans living in $\mathrm{O}_{3}$ polluted areas. Chronic effects of $\mathrm{O}_{3}$ exposure on humans have been addressed primarily with cross-sectional epidemiological studies, for example by SCHWARTZ et al. [15] as well as STERN et al. [16], who reported reduced levels of FVC and FEV1 after prolonged ozone exposure in both children and adults. However, the findings of this type of study design have been regarded as inconclusive because of the lack of precise information of exposure and the difficulty of controlling for confounding factors [24]. The coincident effect of other pollutants, for example $\mathrm{NO}_{2}$, TSP or sulphates, limited the observed relationship between ozone and the lung function parameters FVC and FEV1 $[15,16,31]$. Thereore, selected study locations free of industry in the vicinity and characterized by low concentrations of $\mathrm{NO}_{2}$ and $\mathrm{SO}_{2}$ were selected for the present study. More recently, TAGER et al. [32] studied 175 first-year students, who lived in selected areas of California for all of their lives, and assessed the $\mathrm{O}_{3}$ exposure on the basis of lifetime residential history. Multiple, linear regression analyses showed a consistently negative relation between estimates of lifetime exposure to ozone and flow rates that reflect the physiology of pulmonary small airways.

Reproducible associations of ambient $\mathrm{O}_{3}$ exposure in the summer and diminished increase in FVC and FEV1 in two consecutive years was observed, whereas there was no association in the winter period. Taking the results of many chamber and epidemiological studies into account, this demonstrates a real $\mathrm{O}_{3}$ effect in both summer periods.

During winter, children in group $\mathrm{M}$ and $\mathrm{H}$ showed a slightly higher increase in the FEV1 and FVC compared to children in group L. This might reflect that some children catch up in lung function deficits during the winter season. However, only one observation period during the winter season was investigated, therefore, the data concerning whether there is a tendency to make up for retardation of growth during summer is not conclusive for this hypothesis.

\section{Conclusion}

To conclude, decreases in forced vital capacity and forced expiratory volume in one second were quantitatively associated with the level of mean ambient ozone over a 6-month summer period which were very similar in two consecutive years. The observations in the present study are in accordance with animal studies, which favour the chronic effects of ambient ozone concentration. The observation period was too short to address the issue of whether changes during chronic ozone exposure over several months are reversible or not. Therefore, further epidemiological studies over a longer observation period are necessary. 
Acknowledgements. The authors would like to thank the children and their parents for their tireless cooperation as well as the headteachers for their consistent support. They would also like to thank V. Legner, H. Veigel, M.Wiederkehr, C. Janzen, E. Gerold, V. Thies and O. Kappert for their outstanding collaboration in the schools. Data on ozone exposure was kindly supplied by the Regional Environmental Protection Agency (LFU, Baden-Württemberg).

\section{References}

1. Lippman M. Health Effects of Ozone. A critical review. JAPCA 1989; 39: 672-695.

2. Spektor DM, Thurston GD, Mao J, He D, Hayes C, Lippman M. Effects of single- and multiday ozone exposures on respiratory function in active normal children. Environ Res 1991; 55: 107-122.

3. Hoek G, Brunekreef B, Kosterink P, Berg v.d. R, Hofschreuder P. Effect of Ambient ozone on peak expiratory flow of exercising children in the Netherlands. Arch Environ Health 1993; 48: 27-32.

4. Braun-Fahrländer Ch, Künzli N, Domenighetti G, Carell $\mathrm{CF}$, Ackermann-Liebrich U. Acute effects of respiratory function of Swiss schoolchildren after a 10-minute heavy exercise. Pediatr Pulmonol 1994; 17: 169-177.

5. Ulmer C, Kopp M, Ihorst G, Frischer T, Forster J, Kuehr J. Effects of ambient ozone exposures during the spring and summer of 1994 on pulmonary function of schoolchildren. Pediatr Pulmonol 1997; 23: 344-353.

6. Castillejos M, Gold DR, Dockery D, Tosteson T, Baum T, Speizer FE. Effects of ambient ozone on respiratory function and symptoms in Mexico City schoolchildren. Am Rev Respir Dis 1992; 145: 276-282.

7. Hoek G, Fischer P, Bruinekreef B, Lebret E, Hofschreuder P, Mennen MG. Acute effects of ambient ozone on pulmonary function of children in the Netherlands. Am Rev Respir Dis 1993; 147: 111-117.

8. Kinney PL, Ware JH, Spengler JD, Dockery DW, Speizer FE, Ferris BG. Short-term pulmonary function change in association with ozone levels. Am Rev Respir Dis 1989; 139: $56-61$.

9. Lioy PJ, Vollmuth TA, Lippmann M. Persistence of peak flow decrement in children following ozone exposures exceeding the national ambient air quality standard. JAPCA 1985; 35: 1069-1071.

10. Avol EL, Linn WS, Shamoo DA, et al. Short-term respiratory effects of photochemical oxidant exposure in exercising children. JAPCA 1987; 37: 158-162.

11. Lippmann M, Lioy PJ, Leikauf G, et al. Effects of ozone on the pulmonary function of children. Adv in Modern Environ Toxicol 1983; 5: 423.

12. Kinney PJ, Ware JH, Spengler JD. A critical evaluation of acute ozone epidemiology results. Arch Environ Health 1988; 43: 168-173.

13. Spektor DM, Lippmann M, Lioy PJ, et al. Effects of ambient ozone on respiratory function in active normal children. Am Rev Respir Dis 1988; 137: 313-320.

14. McDonnell WF, Horstman DH, Sa'id A, House DE. Reproducibility of individual response to ozone exposure. Am Rev Respir Dis 1985; 131: 36-40.

15. Schwartz J. Lung function and chronic exposure to air pollution: a cross-sectional analysis of NHANES II. Environ Res 1989; 50: 309-321.

16. Stern BR, Raizenne ME, Burnett RT, Jones L, Kearney J, Franklin CA. Air pollution and childhood respiratory health: exposure to sulfate and ozone in 10 Canadian rural communities. Environ Res 1994; 66: 125-142.

17. Frischer T, Studnicka M, Gartner C, et al. Lung function growth and ambient ozone. A three years population study in schoolchildren. Am J Respir Crit Care Med 1999; 160, (2): 390-396.

18. Meinert R, Frischer T, Karmaus W, Kuehr J. Influence of skin prick test criteria on estimation of prevalence and incidence of allergic sensitization in children. Allergy 1994; 49: 526-532.

19. Dockery DW, Pope AC, Xu X, et al. An association between air pollution and mortality in six U.S. cities. NEJM 1993; 329: 1753-1759.

20. U.S. Environmental Protection Agency Office. 1991. National Air Quality and Emissions Trends Report. Office of Air Quality Planning and Standards, Research Triangle Park, NC. 450-R-92-001.

21. Spengler JD, Koutrakis P, Dockery DW, Raizenne M, Speizer FE. Health effects of acid aerosols on North American children: air pollution exposures. Environ Health Perspect 1996; 104: 492-499.

22. Jörres R, Nowak D, Magnussen H, Specking P, Koschyk $\mathrm{S}$. The effect of ozone exposure on allergen responsiveness in subjects with asthma or rhinitis. Am J Respir Crit Care Med 1996; 153: 56-64.

23. Kollipara S, Connors MH. Lack of seasonal influence on growth hormone therapy. Growth 1985; 49: 341-345.

24. Bascom R, Bromberg PA, Costa DA, et al. Health effects of outdoor air pollution. State of the Art. Am J Respir Crit Care Med 1996; 153: 3-50.

25. Kopp MV, Ulmer C, Ihorst $\mathrm{G}$, et al. Upper airway inflammation in children exposed to ambient ozone and potential signs of adaptation. Eur Respir J 1999; 14: 854861.

26. Folinsbee LJ, Bedi JF, Horvath SM. Respiratory responses in humans repeatedly exposed to low concentrations of ozone. Am Rev Respir Dis 1980; 121: 431-439.

27. Harkema JR, Plopper CG, Hyde DM, St. George JA, Wilson DW, Dungworth DL. Response of the macaque nasal epithelium to ambient ozone levels of ozone. A morphologic and morphometric study of the transitional and respiratory epithelium. Am J Pathol 1987; 128: 29-44.

28. Tyler WS, Tyler NK, Last JA, Barstow TJ, Magliano DJ, Hinds DM. Effects of ozone on lung and somatic growth. Pair fed rats after ozone exposure and recovery periods. Toxicology 1987; 46: 1-20.

29. Tyler WS, Tyler NK, Last JA, Gillespie MJ, Barstow TJ. Comparison of daily and seasonal exposures of young monkeys to ozone. Toxicology 1988; 50: 131-144.

30. Chang L, Miller FJ, Ultman J, et al. Alveolar epithelial cell injuries by subchronic exposure to low concentrations of ozone correlate with cumulative exposure. Toxicol Appl Pharmacol 1991; 109: 219-234.

31. Detels R, Tashkin DP, Sayre JW, et al. The UCLA population studies of CORD: X. A cohort study of changes in respiratory function associated with chronic exposure to $\mathrm{SO}_{2}, \mathrm{NO}_{2}$ and hydrocarbons. Am J Public Health 1991; 81: 350-359.

32. Tager IB, Kunzli N, Lurmann F, Ngo L, Segal M, Balmes J. Methods development for epidemiologic investigations of the health effects of prolonged ozone exposure. Part II. An approach to retrospective estimation of lifetime ozone exposure using a questionnaire and ambient monitoring data (California sites). Res Rep Health Eff Inst 1998; 81: 27-78. 